\title{
PREFACE TO THE UNIVERSITY OF TEXAS PRESS EDITION
}

The first edition of this book, published in 1979, was based primarily on a series of collections, observations, and research on Gulf of California fishes in the 1960s and 1970s. Since that time we have continued studying and monitoring Gulf fish communities, looking for trends in the relative abundance of reef-fish species. News journalists have been justly lamenting the drastic declines in certain populations of commercial and sport fishes in the Sea of Cortez (for example, Tom Knudson's series, "A Dying Sea," in the Sacramento Bee, December 10-13, 1995), and others have written reviews warning of the catastrophic depletion of global fish populations due to overfishing (e.g., Parfit, 1995; Safina, 1995; Christensen and Pauly, 1995; Dayton et al., 1995; and Alverson et al., 1994). There have been significant reductions in populations of sharks, mantas and other large rays, sea turtles, the vaquita, and a wide variety of teleost fishes, including the endangered totoaba, several corvinas, large groupers and snappers, yellowtail, billfishes, and several species composing the shrimp bycatch (Nava-Romo, 1994). All of these declines have been attributed to overfishing by foreign and/or Mexican commercial fleets. Summer cruises led by the senior author among the unpopulated islands and coasts of the upper and central Gulf in 1993 and 1994 conducted censuses of reef-fish populations and collected data on the Mexican commercial and sportfishing fleets (Thomson and Mesnick, 1993; Thomson et al., 1996). It was depressing to observe the shark fishery killing not only hammerheads and many other kinds of sharks but incidentally killing mantas, large stingrays and bat rays, billfishes, and tunas, as well as bottlenose and common dolphins in their gill nets. Also, several recent studies have documented that incidental capture in gill nets is the greatest threat to the continued existence of the vaquita or Gulf of California harbor porpoise, the marine cetacean in greatest danger of extinction, whose small population is found only in the upper Gulf. Our scuba censuses showed the larger reef fishes, such as groupers, snappers, and parrotfishes, to be considerably less abundant than they were 25 years ago. However, we were gratified to find that the majority of smaller-sized reef fishes seem to have maintained their relative abundance of earlier days. In general, populations of fishes that have not been targeted for exploitation are doing well and fishwatchers can still enjoy colorful reef-fish scenarios.

Since 1979, one of us (LTF) has been living in the Guaymas/San Carlos area of coastal Sonora and, along with several students and colleagues, has had many occasions to observe the local reef fishes. The still scenically picturesque Bay of Guaymas itself is now essentially an underwater biological "desert" due to largely uncontrolled pollution originating from the many ships that utilize this largest commercial shipping and fishing (especially shrimping) port in the Gulf of California, and from wastewater effluents from sardine-, shrimp-, and other seafood-processing plants located there. But outside the localized site of Guaymas Bay, pollution is still minimal and underwater communities appear largely unaffected. Nonetheless, on the rocky reefs around and to the north of the nearby tourist mecca of San Carlos, similar declines in 
the populations of targeted food and sport fishes, especially the larger-sized species mentioned above, have been seen. The declines have been more marked in recent years, yet the regional small-scale commercial ( panga) gill-net and set-line fisheries as well as the sport fishery, including illegal spearfishing by divers of large fishes (which represent the maximum reproductive potential for their species), continues to be minimally regulated in this scenic area slated for further expansion of marine-based tourist services and facilities.

"Traditional" tourism developments in several other areas of the Gulf are on the increase, and, whether catches of desired sport and food fishes are destined for export or for local consumption (in restaurants, for example), their populations will likely continue to be stressed. There are no easy solutions to the problem. In the past 15 years, Mexico has undergone two major economic crises, and continued tourism development is seen as a principal way of increasing the country's depleted foreign-exchange reserves. Also, Mexico's burgeoning human population and concomitant increase in coastal settlement place increasing stresses on the Gulf's diverse natural resources and, in the absence of ecologically realistic management, several regional fisheries (albeit mainly involving non-reef fishes, such as sharks and sardines) are in decline and may be on the verge of collapse. Space does not permit further discussion of this complex topic; thus, the reader is referred to the general articles cited above and to recent socioeconomic analyses that treat the magnitude of the problem in the Gulf of California and provide some potential solutions (e.g., McGuire and Greenberg, 1993).

On the bright side, however, ecologically based tourism ("ecotourism"), with its necessary concern for conservation of intact and viable ecosystems, is actively being promoted in the Gulf, and increasing numbers of tourists are experiencing the rich biodiversity of its waters and unique island archipelagos with minimal impact on the environment. Marine life in the upper Gulf of California will benefit from the Mexican government's declaration in 1993 that a large part of that area is now a biosphere reserve whose complex management plan is beginning to be implemented ("complex" in that it necessarily takes into account indigenous human as well as animal and plant populations). Also, several international conservation organizations (e.g., Conservation International and the World Wildlife Fund), as well as regional institutions and agencies, are working to alleviate the stresses on Gulf ecosystems. In addition to important environmental/biodiversity and sustainable fisheries research programs being carried out at Mexican agencies and centers of higher education (e.g., INE/ SEMARNAP, CECARENA/ITESM, CIAD, IMADES [formerly CIDESON/CES], CICIMAR/IPN, DICTUS/UNISON, CONABIO, CICESE, CIB, UABC, UABCS, ICMYL/UNAM, and CRIPs/INP), a few relatively new, non-governmental conservation/educational organizations, such as the Intercultural Center for the Study of Deserts and Oceans (CEDO), Pronatura-Sonora, the Mexican Fund for Conservation of Nature (FMCN), the Mexican Foundation for Environmental Education (FUMEA), and, especially, Conservation International-Mexico's (CIMEX) Gulf of California Program, have been instrumental in defining problems and in initiating meaningful dialogue among the different sectors of the tourism and fishing industries, governmental regulatory agencies, the small-scale fishing communities, and the populace at large. Furthermore, through projects now operating, these organizations are attempting to educate resources users and promulgate a conservation ethic linked to a truly sustainable development of the resources of the Sea of Cortez. Their task is far from easy, and we wish continued success to these organizations and others like them. 
In this new edition, we have added recent changes in the classification and nomenclature of Sea of Cortez reef fishes as well as updated information on their distribution and ecology. We have included a few new photographs and illustrations of fishes but added or replaced only ten species to the 1979 checklist, a testimony to the relative completeness of the first edition. The classification of reef fishes in the checklist (Appendix I) has been revised to keep up-to-date on recent changes in fish taxonomy and systematics, but the family sequence in the main text has been minimally altered. We have added relevant references to our bibliography of Sea of Cortez reef fishes and have combined the "General" and "Specific" Bibliographies for ease of reference. We hope that users of this book will find that it meets their needs in learning about the reef fishes of the Sea of Cortez.

\section{ACKNOWLEDGMENTS}

In addition to the many other ichthyologists whose recent research and publications have increased our knowledge of fishes in the Gulf of California and other relevant areas of the eastern Pacific Ocean (see the Bibliography), we especially thank Jerry Allen and Ross Robertson for their comprehensive book Fishes of the Tropical Eastern Pacific (1994). It was a valuable reference in our revision, as were many sections (by several authors) of Volumes II and III of the Guía FAO para la identificación de especies para los fines de la pesca, Pacífico centro-oriental, vertebrados, partes 1 y 2 [FAO Guide to the Identification of Species for Fishing Purposes, Central Eastern Pacific, Vertebrates, Parts 1 and 2] (1995), edited by Walter Fischer and others of the United Nations Food and Agriculture Organization. It is gratifying to have recently published references on fishes relevant to the Gulf of California by Milton Love (1996), Bill Eschmeyer (1990 and, with the late Earl Herald, 1983), Joe Nelson (1994), Paul Humann (1993), Norma Chirichigno (1982), Myrna López and Bill Bussing (1982), Humberto Chávez (1985), L. Abitia-Cárdenas et al. (1994), J. de la Cruz et al. (1994), and Albert van der Heiden (with coauthor, 1990). We also thank José Luis Castro-Agüirre, Héctor Espinosa, Shelton Applegate, Alejandro Yáñez-Arancibia, and their students for their fine work on Mexican marine fishes.

We are grateful to Philip A. Hastings, Curator of Fishes at Scripps Institution of Oceanography, La Jolla, CA, for his considerable help in all phases of the revision, and to him and Sarah Mesnick for their review of the blennioid fishes section, and to Phil Heemstra for checking the section on sea basses and groupers. We also thank Neff Nash and the many students in D. A. Thomson's marine ecology and ichthyology classes, and especially University of Arizona graduate students Michael Brogan, Matthew Gilligan, Phil Hastings, Guy Hoelzer, Sarah Mesnick, Christopher Petersen, and Fernando Zapata for their doctoral research on reef fishes. The senior author credits Shaun Pipes for helping him to resume his scuba diving in Gulf waters after a long hiatus.

We thank ITESM-Campus Guaymas graduate students J. Manuel Nava and Juan Carlos Barrera for their master's theses on Gulf fishes, and Jorge Torre, Carlos Navarro, Raúl Molina, Ana Luisa Figueroa, Gerardo Alvarez-Manilla, Carlos Pantoja, Guillermo Soberón, Alejandro Robles, Mario Huerta, Lorenzo Juárez, Tatsushi Nakano, Cristina Goettsch, Javier Paz, Bruno Castrezana, Enrique Arizmendi, Rocio ("Cora”) and Patricia Güereca, "Melos" Guzmán, Omar Vidal, Patricia Aguilar, and many other students in L. T. Findley's ichthyology classes for their collections, obser- 
vations, and assistance in curating fish specimens and for data capture (e.g., Findley et al., 1996).

For various recent contributions on Gulf of California fishes, we thank J. L. CastroAgüirre, Humberto Chávez, Eduardo Balart, Felipe Galván, Albert van der Heiden, Sergio Rodríguez, Héctor Plascencia, Sergio Mussot, Héctor Espinosa, Patricia Fuentes, Leticia Huidobro, Juan Jacobo Schmitter, Kurt Kotrschal, Phil Hastings, Sarah Mesnick, Richard H. Rosenblatt, H. J. Walker, Cynthia Klepadlo, Jeff Seigel, Martha Román, José Campoy, Alejandro Varela, Miguel Ángel Cisneros, Juan Manuel García, Jorge Wong, Richard Schleining, Rubén Rodríguez, and the late (great) Peter Whitehead.

We thank the following scientists for their research, support, advice, and encouragement: Juan Carlos Barrera from INE/SEMARNAP at IMADES in Hermosillo, Sonora; Inocencio Higuera from CIAD in Hermosillo; Albert M. van der Heiden from the Mazatlán, Sinaloa, Unit of CIAD; Héctor Espinosa from the National Institute of Biology at UNAM in Mexico City; Jorge Soberón from CONABIO in Mexico City; W. Linn Montgomery from the University of Northern Arizona in Flagstaff; Phil Pister from the Desert Fishes Council; Bob Lea from the California Department of Fish and Game in Monterey; Dean Hendrickson from the Texas Natural History Collections of the University of Texas in Austin; John McEachran from Texas A\&M University in College Station; Peggy Turk-Boyer, Carlos Navarro, and Richard Cudney from CEDO in Puerto Peñasco, Sonora; "Hans" Herrmann from Pronatura in Mexico City; and Alejandro Robles and "Machangeles" Carvajal from Conservation International in Mexico City and Guaymas, Sonora, two people who have provided many professional courtesies to L. T. Findley, making possible his work on this revision.

We again wish to thank our wives, Jenean Thomson and Sandra (Sonnie) Hull Findley, for their long-term support, and Natalie and Elizabeth Findley for assistance in collecting and for keeping their father in a good mood (most of the time).

Since this new edition required a considerable subvention we are grateful to all of the following persons and institutions who contributed funds to insure the publication of the book. We especially thank the Sonoran Sea Aquarium, the University of Arizona Provost's Office, Jon Sysel, Peggy Turk-Boyer \& Rick Boyer, John \& Carol Bonhurst, Tony Swensrud, Kurt Thomson, and Nancy \& Bill Kane. In addition, several of our friends and colleagues contributed generously to the subvention: Ed \& Judy Boyer, Rick Brusca \& Wendy Moore, Luis Bourillon \& Marisol Tordesillas, Frank Cipriano, Susan Crowell, Lynda Delph-Lively \& Curt Lively, Trica \& Dave Hawkins, Mark \& Janet Helvey, Guy Hoelzer, Yvonne Maluf, Katrina Mangin, Rick McCourt \& Becky Simmons, Sarah Mesnick, Sam \& Beth Mesnick, J Nichols, Chris Petersen \& Helen Hess, Polly Rankin, Cynthia Riginos, Steve Shuster \& Michelle Pitts, Jeff Seminoff, and Fernando Zapata. Special thanks and sincere appreciation is due to Sarah Mesnick and Shaun Pipes for their invaluable help in raising funds. Achieving the subvention would not have been possible without them.

Finally, we thank the staff of the University of Texas Press for their considerable effort in making possible this new edition.

D. A. THOMSON
TUCSON, ARIZONA
L. T. FINDLEY

GUAYMAS, SONORA

September 1999

\author{
A. N. KERSTITCH \\ TUCSON, ARIZONA
}


REEF FISHES OF THE SEA OF CORTEZ 
THIS PAGE INTENTIONALLY LEFT BLANK 